\title{
Application of the Biolog® Identification System for Aflatoxin-Producing Fungi Associated with Maize (Zea mays L.) Contamination in Romania
}

\author{
Irina SMEU ${ }^{1 *}$, Elena Mirela CUCU ${ }^{1}$, Alina Alexandra DOBRE ${ }^{1}$, Hellene CASIAN ${ }^{2}$ \\ ${ }^{1}$ National R\&D Institute for Food Bioresources - IBA Bucharest, Microbiology-ELISA Laboratory, $6^{\text {th }}$ Dinu Vintilă \\ Street, $2^{\text {nd }}$ District, 020323 Bucharest, Romania \\ ${ }^{2}$ University of Agronomic Sciences and Veterinary Medicine of Bucharest, Faculty of Agriculture, 59 ${ }^{\text {th }}$ Mărăști \\ Boulevard, $1^{\text {st }}$ District, 011464 Bucharest, Romania \\ *corresponding author: irina.smeu@bioresurse.ro
}

Bulletin UASVM series Agriculture 77(2) / 2020

Print ISSN 1843-5246; Electronic ISSN 1843-5386

DOI:10.15835/buasvmcn-agr: 2020.0015

\begin{abstract}
Cereals are very susceptible to fungal attacks. Fungi have a unique biochemical pathway to assimilate a vast array of available substrates and produce toxic secondary metabolites, such as mycotoxins, which represent a clear public health concern. In this context, a maize survey was conducted in order to assess the diversity of mycotoxin-producing fungi. Low levels of total aflatoxins, acceptable by the European Union, were detected in maize samples. A semi-automated Biolog® Microbial Identification System was used for the identification of the fungal strains. Enzyme-linked immunosorbent assay (ELISA) was used for the quantification of total aflatoxins. The results indicated that Fusarium udum and Rhizopus oryzae were the prevalent fungi for the assessed maize samples, while both control and treated samples showed low levels of total aflatoxins, which did not exceed $1.5 \mu \mathrm{g}$ $\mathrm{kg}^{-1}$. The registered total aflatoxin concentrations were consistent with the European regulations.
\end{abstract}

Keywords: aflatoxins, Biolog® system, maize

\section{INTRODUCTION}

Maize (Zea mays L.) is one of the most important cereals in the world with an estimated global production of approximately 1123.33 million tons produced on 191.65 million hectares in 20182019 (USDA, 2020). At European Union (EU) level, maize represented the most prevalent cereal crop in 2018 and registered a percent of $46.4 \%$ of the total cereal cultivated area (INS, 2019). In 2019, there was registered a maize cultivated area of 5426.34 thousand hectares in the EU, 165.06 thousand hectares more than in 2018 (EUROSTAT, 2020a), while Romania noted the largest maize cultivated area and production in the EU (EUROSTAT, 2020b).
Maize crops are very susceptible to fungal attacks, both in the field and during storage (Mutiga et al., 2019). Depending on environmental conditions, a fungal infection might be mainly produced by species of Aspergillus (Sserumaga et al., 2020), Fusarium (Castañares et al., 2019) and Penicillium (Ekwomadu et al., 2018). Such fungi possess a unique biochemical pathway to assimilate a vast array of available substrates which may result in the production of toxic secondary metabolites, such as mycotoxins (Singh, 2009).

Mycotoxins are a group of toxic compounds produced by filamentous fungi, which pose a health risk to both human and animal welfare, since 
they can be transferred across the food and feed production chains. Under specific environmental conditions, toxigenic fungal species belonging to the genera Aspergillus, Fusarium, Penicillium, Altenaria and Claviceps colonize their host and produce mycotoxins, such as aflatoxins (A. flavus), deoxynivalenol ( $F$. graminearum), zearalenone (F. graminearum, F. culmorum), fumonisins ( $F$. verticillioides), ochratoxin A (A. ochraceus) and patulin (Penicillium, Aspergillus) (Puel et al., 2010; Döll and Dänicke, 2011; Sobrova et al., 2010; Kagot et al., 2019). Currently, over 300 mycotoxins differing in chemical diversity and toxicity have been identified, while twenty to thirty of them have shown a great importance to their adverse health effects on vertebrates upon ingestion (Kagot et al., 2019).

Aflatoxins are a major class of toxic and carcinogenic mycotoxins produced primarily by fungi belonging to Aspergillus section Flavi, mainly Aspergillus flavus and A. parasiticus (Klich, 2007; Sserumaga et al., 2020). These toxins are found as natural contaminant in plant-based foods, including tree nuts (Campbell at al., 2003), groundnuts (Lien et al., 2019), cottonseeds (JaimeGarcia and Cotty, 2003), spices (Singh and Cotty, 2017), cereals and derivatives (Majeed etal., 2013). Prolonged or chronic exposure levels of aflatoxins can lead to acute hepatitis (Ngindu et al., 1982), liver cancer (Fedeles et al., 2017), lung cancer (Georggiett et al., 2000) and gastric cancer (Eom et al., 2013). Aflatoxin contamination in animal feed is harmful to livestock. Intake of mycotoxins such as aflatoxins by livestock may lead to residues and its metabolites, such as aflatoxin M1 and aflatoxicol which are deposited in meat, milk and eggs (Li et al., 2010; Díaz-Zaragoza et al., 2014; Tadesse et al., 2020). The four major aflatoxins are B1, B2, G1 and $\mathrm{G} 2$, of which aflatoxin B1 is among the most potent mutagenic and carcinogenic substances (Campone et al., 2011), reason for which it was classified by the International Agency for Research on Cancer as a Group 1 carcinogen (IARC, 1993). Aflatoxins became a main concern for maize production in Europe since 2003, when a severe outbreak was observed in Italy (Piva et al., 2006), while Serbia and Romania also faced contamination problems as of 2012 (Lević et al., 2013). Thus, given their highly toxigenic nature, the European Union level strictly regulates aflatoxins, such that maximum allowable limits in various commodities should not exceed $4 \mu \mathrm{g} \mathrm{kg}^{-1}$ aflatoxin B1 and $10 \mu \mathrm{gg}^{-1}$ total aflatoxins for maize to be subjected to sorting or other physical treatment before human consumption or use as an ingredient in foodstuffs (EC Commission Regulation No. 1881/2006).

In this context, the purpose of this study was to investigate the incidence of aflatoxin-producing fungi within maize samples collected during the 2019 harvest from fields located in two Romanian counties. For this purpose, a Biolog ${ }^{\circledR}$ system was used for rapid identification and characterization of the fungal strains.

\section{MATERIALS AND METHODS}

\section{Plant material and field trials}

Field trials were organized for studying the prevalence of mycotoxin-producing fungi and total aflatoxins in maize samples. Two field locations were chosen in two major cereal-producing areas of Romania during the 2019 maize growing season (Fig. 1). Thus, experimental field trials were located in Iași County (Macroregion 2, NorthEastern development region) and Arad County (Macroregion 4, Western development region). In each location, the previous crop was represented by wheat. The tillage involved the summer plowing at $30 \mathrm{~cm}$, followed by levelling and preparation of the germinal bed.

A type of hybrid, often cultivated in Romania, was selected as plant material in this study. The main characteristics of the hybrid for which it was chosen were its early flowering, strong and healthy stems, good tolerance to cold, excellent vigor at sunrise, deep root and vigorous strain, excellent synchronicity between pollen release and silk appearance (early and aggressive flowering), stability and reduced production losses under heat and water stress. The plant material registered a physical purity of $99 \%$ and a MMB index (the mass of a thousand grains) of $253.9 \mathrm{~g}$. It was sown at the end of April in both locations. There was noted a sowing density of 72.000 germinator grains ha $^{-1}$ with a sowing depth of $5 \mathrm{~cm}$. The distance between rows was $60 \mathrm{~cm}$, while the distance between grains per row was $23 \mathrm{~cm}$. In both locations, 1 ha received treatment with an experimental biocontrol product based on a native Aspergillus flavus atoxigenic strain (Treated samples) and 1 ha served as a control field, where no fungal treatment was applied (Control samples). Three fertilization treatments were applied that are as follows: i) 150 


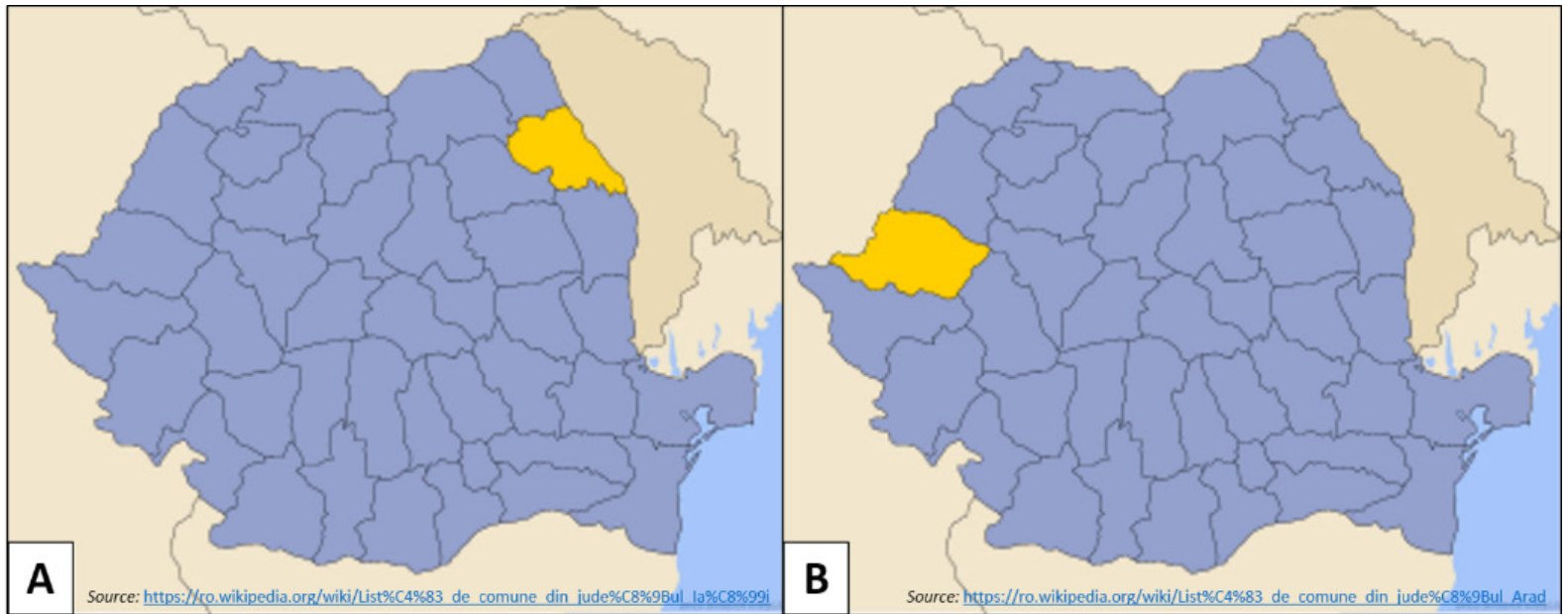

Figure 1. Location of experimental field trials: (A) Iași County; (B) Arad County

$\mathrm{kg}$ urea incorporated during the preparation of the germinal bed; ii) $20 \mathrm{~kg}$ ha- 1 start biostimulator for seed germination (microgranulated product with a formula of $8 \% \mathrm{~N}-28 \% \mathrm{P} 2 \mathrm{O} 5-14 \% \mathrm{CaO}-23$ $\%$ SO3 - $2 \% \mathrm{Zn}$ ), in combination with a complex fertilizer with a 20:20:0 ratio (the N : P : K ratio) which has $0.05 \% \mathrm{Zn}$, applied in a dose of $200 \mathrm{~kg}$ ha-1 during sowing; iii) $200 \mathrm{~kg} \mathrm{ha}^{-1}$ ammonium nitrate during weed removal. The weed control was performed mechanically at V4 and V8 stages. The biological treatment was distributed with a fertilizer spreader ( $\left.25 \mathrm{~kg} \mathrm{ha}^{-1}\right)$, at stem elongation growth stage, and 35-39 BBCH- identification keys (Biologische Bundesanstalt, Bundessortenamt und Chemische Industrie - German scale used to identify the phenotypical development stages of a plant), after soil tillage (Mauro et al., 2018). Both control and treated maize (2 kg each) were sampled immediately after harvest (moisture content $16 \%$ ) in triplicates. Upon their arrival in the ELISA laboratory, all samples $(n=12)$ were transferred into paper bags and stored at room temperature in a dark and dry place for two days, until their assessment.

\section{Microbiological analysis}

Yeasts and moulds were monitored. An amount of $10 \mathrm{~g}$ of maize grains was aseptically removed from the package using a sterile spatula and transferred to a sterile filter stomacher bag (Seward Limited, UK), containing $90 \mathrm{~mL}$ sterile homogenate solution $(0.85 \% \mathrm{NaCl}$ and $0.1 \%$ neutralized bacteriological peptone). The samples were homogenized using a stomacher (Seward
Limited, UK) for $30 \mathrm{~s}$ at room temperature. Tenfold dilution series were made in sterile peptone saline solution as needed for plating. A volume of $1 \mathrm{~mL}$ of the appropriate sample dilution was plated on Malt Extract Agar (MEA) (Oxoid, UK) and incubated at $25^{\circ} \mathrm{C}$, for 7 days to allow for fungal growth. Fungal counts were expressed as log cfu g- ${ }^{1}$.

\section{Fungal isolation and identification using the Biolog ${ }^{\circledR}$ Microbial Identification Sys- tem}

The Biolog ${ }^{\circledR}$ Microbial Identification System (Biolog, Inc., SUA) identifies, based on redox reactions, microorganisms which occur in the wells of a microplate. The identification system is applicable to both Gram positive and Gram negative bacteria, yeasts and fungi. The equipment analyzes the ability of the microbial cell to metabolize the main classes of biochemical substances, while it also determines other important physiological properties of the analyzed microorganism, such as $\mathrm{pH}$, tollerance to lactic acid, chemical sensitivity.

The technology of using a powerful carbon source allows a precise identification of microorganisms by producing a characteristic pattern from discrete test reactions which take place within the 96 wells microplate. The biochemical reactions are based on the use of different carbon sources, such as sugars, carboxylic acids, amino acids or peptides, which have the role of biochemically discriminating and characterizing the studied microorganisms. The unique metabolic footprint generated by the microorganism is recorded and compared with the appropriate FF (Filamentous 
Fungi) Biolog ${ }^{\circledR}$ database (Biolog, Inc., SUA) which covers over 400 taxa of fungi from over 120 genera. The reactions that take place in the 96 wells, together with the MicroLog ${ }^{\top M}$ software (Biolog, Inc., SUA) interpretation, provide a high level of accuracy of the results. The identification of the microorganisms implies the completion of some stages. Thus, each isolated fungus was first grown on two plates of 2\% MEA (Oxoid, UK), at 25 ${ }^{\circ} \mathrm{C}$. After an incubation period of 7 days, conidia were collected with sterile cotton swabs. The swabs were dipped into screw-top culture tubes containing $16 \mathrm{~mL}$ Biolog ${ }^{\circledR} \mathrm{FF}$ inoculating fluid. The conidial suspension was adjusted at $75 \%$ transmittance using the Biolog ${ }^{\circledR}$ turbidimeter, model number 21907 (Biolog, Inc., SUA). A volume of $100 \mu \mathrm{L}$ was pipetted into each of the 96 wells of a single Biolog ${ }^{\circledR}$ FF plate for each fungal isolate. In total, there were recovered 34 fungal isolates, 21 fungal isolates from treated samples and 13 isolates from control samples, respectively. The resulting plates were incubated at $25{ }^{\circ} \mathrm{C}$ and the biochemical reactions were recorded using the MicroStation $^{\text {TM }}$ Reader (Biolog, Inc., SUA) with a $590 \mathrm{~nm}$ wavelength filter at 1, 2, 3, 4 and 7 days, as suggested by the manufacturer.

\section{Aflatoxin analysis}

A competitive enzyme linked immunosorbent assay (ELISA) was selected for the quantitative analysis of total aflatoxins. The assessment was performed with commercially available test kits, according to the manufacturer's instructions (Ridascreen ${ }^{\circledR}$ Aflatoxin Total, R-Biopharm AG, Germany).Thus, all sampleswere firstfinely ground using a laboratory mill (MRC Ltd., Israel) and mixed thoroughly to achieve complete homogenization. Furthermore, 2 grams of grinded sample were homogenized in $10 \mathrm{~mL}$ methanol/distilled water $(70 / 30 ; \mathrm{v} / \mathrm{v})$ and mixed vigorously for 10 minutes at room temperature using an orbital shaker (GFL Gesellschaft für Labortechnik mbH, Germany). All extracts were then filtered using a grade 1 filter paper (Whatman ${ }^{\mathrm{TM}}, \mathrm{UK}$ ) and the obtained filtrates were further diluted in $600 \mu \mathrm{L}$ distilled water $(100 / 600 ; \mathrm{v} / \mathrm{v})$. A sufficient number of microtiter wells was inserted in to the microwell holder for all standards, samples and for the reference material (naturally contaminated aflatoxin corn) to be run in duplicate. Fifty microliters standard solutions, prepared samples and reference material were employed to separate duplicate wells. A volume of
$50 \mu \mathrm{L}$ of the enzyme conjugate was added to each well, followed by $50 \mu \mathrm{L}$ of the antibody solution. The plate was gently mixed by hand and incubated for 30 minutes at room temperature in the dark. After the incubation period, the liquid was poured out of the wells and the plate was vigorously taped upside down against absorbent paper to ensure complete removal of liquid from the wells. This was followed by the washing procedure $(250 \mu \mathrm{L}$ washing buffer, repeated three times). A volume of $100 \mu \mathrm{L}$ of substrate/chromogen was added to each well. The plate was again very well mixed by hand and incubated for 15 minutes at room temperature in the dark. After incubation, $100 \mu \mathrm{L}$ of the stop solution were added to each well. The absorbance was measured at $450 \mathrm{~nm}$ using a Sunrise ${ }^{\mathrm{TM}}$ plate reader (Tecan Group Ltd., Switzerland). The RIDA ${ }^{\circledR}$ SOFT Win software was used for the evaluation of the immunoassays. For each sample, two replicates were used. The average of these results was used for data analysis. A mycotoxin quality control material (Trilogy Reference Material, Naturally Contaminated Aflatoxin Corn, Trilogy Analytical Laboratory, Inc., USA) with a total aflatoxin concentration of $5.2 \mu \mathrm{g} \mathrm{kg}{ }^{-1}( \pm 0.8$ $\mu \mathrm{g} \mathrm{kg}^{-1}$ ), of which $4.7 \mu \mathrm{g} \mathrm{kg}^{-1}$ aflatoxin B1 and $0.5 \mu \mathrm{g}$ $\mathrm{kg}^{-1}$ aflatoxin B2, was used for each measurement, to ensure the quality of the analyses.

\section{Data analysis}

Both microbiological and ELISA tests were run in duplicate for each sample $(n=2)$. Microbiological data were expressed as logarithms of the number of colony forming units ( $\mathrm{cfu} \mathrm{g}^{-1}$ ). Descriptive statistics (average and standard deviation) of these results have been employed in data analysis. Reported ELISA results include the recovery of the used quality control material. Data analysis for metabolic profiling of fungi was conducted using BioTek Gen5 software (Biolog, Inc., USA). Statistical analysis was performed using IBM $^{\circledR}$ SPSS $^{\circledR}$ Statistics 20 (IBM Corp., USA). Significance was defined at $P<0.05$.

\section{RESULTS AND DISCUSSION Prevalence of fungal populations}

This study aimed to identify fungal strains from the natural microbiota of the assessed maize samples. The average values of the microbiological results are presented in Fig. 2. The analysis of fungal contamination revealed that the maize samples had fungal counts in the range of 1.30 - 


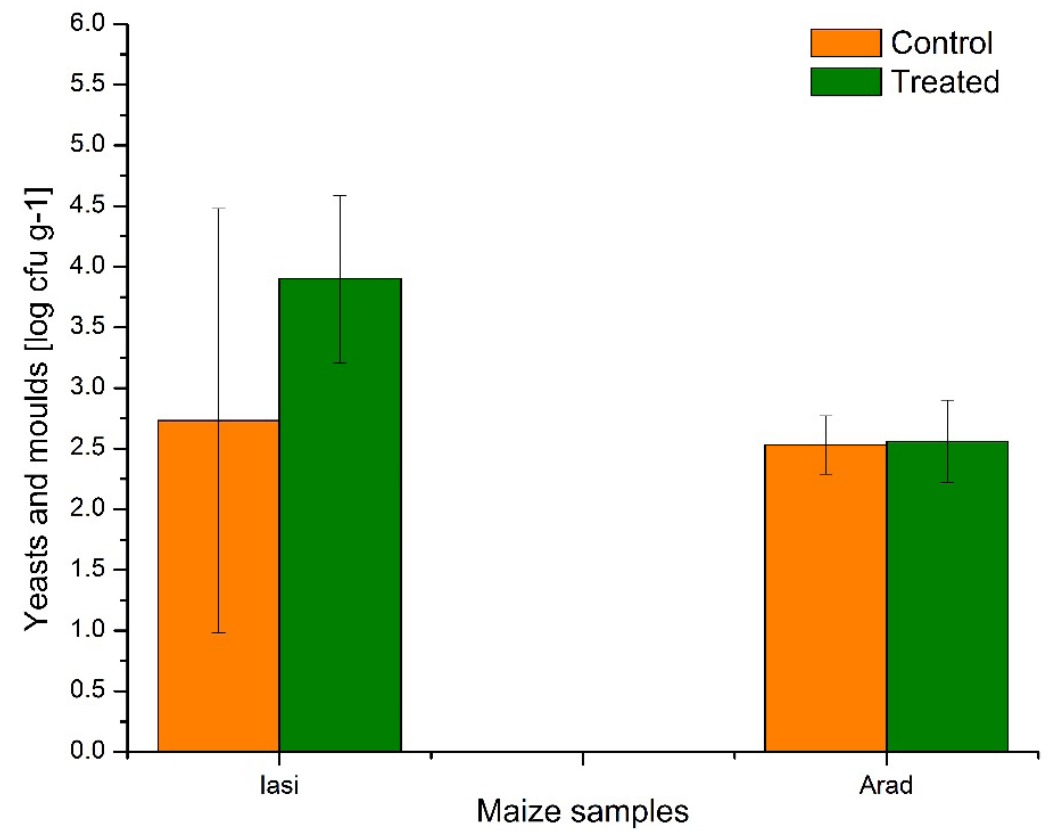

Figure 2. Fungal contamination of maize samples
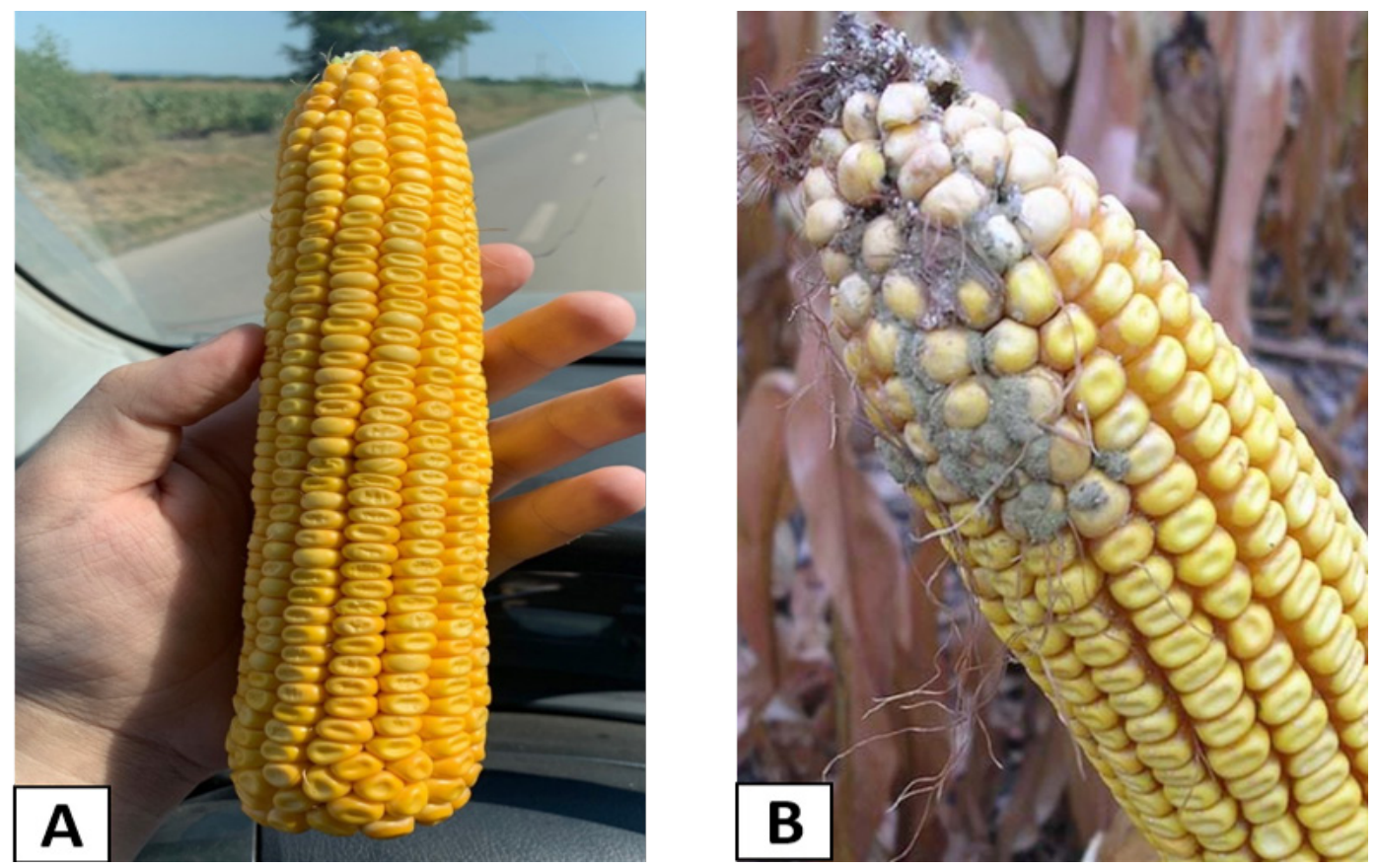

Figure 3. External appearance of maize cobs immediately after harvest: (A) treated maize sample; (B) control maize sample

$4.68 \mathrm{log}_{\mathrm{cfu} \mathrm{g}}{ }^{-1}$. There was noted an average of 2.73 $\log$ cfu g $^{-1}\left( \pm 1.75 \log _{\text {cfu g }}{ }^{-1}\right)$ and $2.56 \operatorname{log~cfu~g}^{-1}( \pm$ $0.34 \operatorname{log~cfu~g}^{-1}$ ) for the control samples, while the treated samples noted $3.90 \mathrm{log}_{\mathrm{cfu} \mathrm{g}^{-1}}( \pm 0.69 \mathrm{log}$ cfu g $^{-1}$ ) and $2.53 \log _{\text {cfu g }}{ }^{-1}\left( \pm 0.24 \log _{\text {cfu g }}{ }^{-1}\right)$ in Iași and Arad, respectively.

In Iași County, the field observations noted that, on the treated plots, the incidence of Fusarium spp. was lower when compared with the control 
plots (Fig. 3). As our results noted higher levels of fungal contamination for the treated samples, this might be attributed to a higher incidence of Ostrinia nubilalis pest, which usually favors the infection of Fusarium spp. and which was noted by the farmers. The incidence of the pest was noted to be lower in the control fields, most likely as a result of the various agronomic treatments that were applied.

The microbiological control of the samples involved not only the quantification of the fungal population, but also the identification of the microorganisms present in the assessed product. Our study confirmed the isolated fungi using the semi-automated Biolog ${ }^{\circledR}$ Microbial Identification System, where the metabolic footprint of the assessed microorganisms was compared with the identification profiles of the FF Database, for filamentous fungi identification (Biolog, Inc., SUA). Thus, the acceptable instrument readings at the end of the incubation period noted levels of the similarity index in the range of 0.685-0.792 (good identification) for Fusarium udum and Rhizopus oryzae (Singh, 2009; Wang et al., 2016).
In our study, Fusarium udum was isolated and identified in a control maize sample from Arad County (Macroregion 4, West development region) using Biolog ${ }^{\circledR}$ system (Fig. 4). Fusarium is one of the most economically important genera of phytopathogenic fungi that can infect maize. Fusarium diseases that affect cereal crops are caused by several Fusarium species or more commonly, co-occurring species (Ferrigo et al., 2016). Fusarium udum is known as the causal agent of a wilt disease on pigeon pea (Cajanus cajan) in tropical regions (Pfenning et al., 2018). However, as other Fusarium species such as F. proliferatum (Fallahi et al., 2019), F. concentricum (Fotso et al., 2002), Fusarium subglutinans (Meca et al., 2009) and F. temperatum (Fallahi et al., 2019), F. udum (Moretti et al., 2007) produces fusaproliferin (FUS), a toxic compound to insect and mammalian cells which causes teratogenic effects in chicken embryos. The fungus causing wilt can survive on infected plant debris in soil for about 2 to 3 years, and it is responsible for causing 16 to $47 \%$ yield loss under favorable environmental conditions (Srivastava et al., 2018). The production of FUS

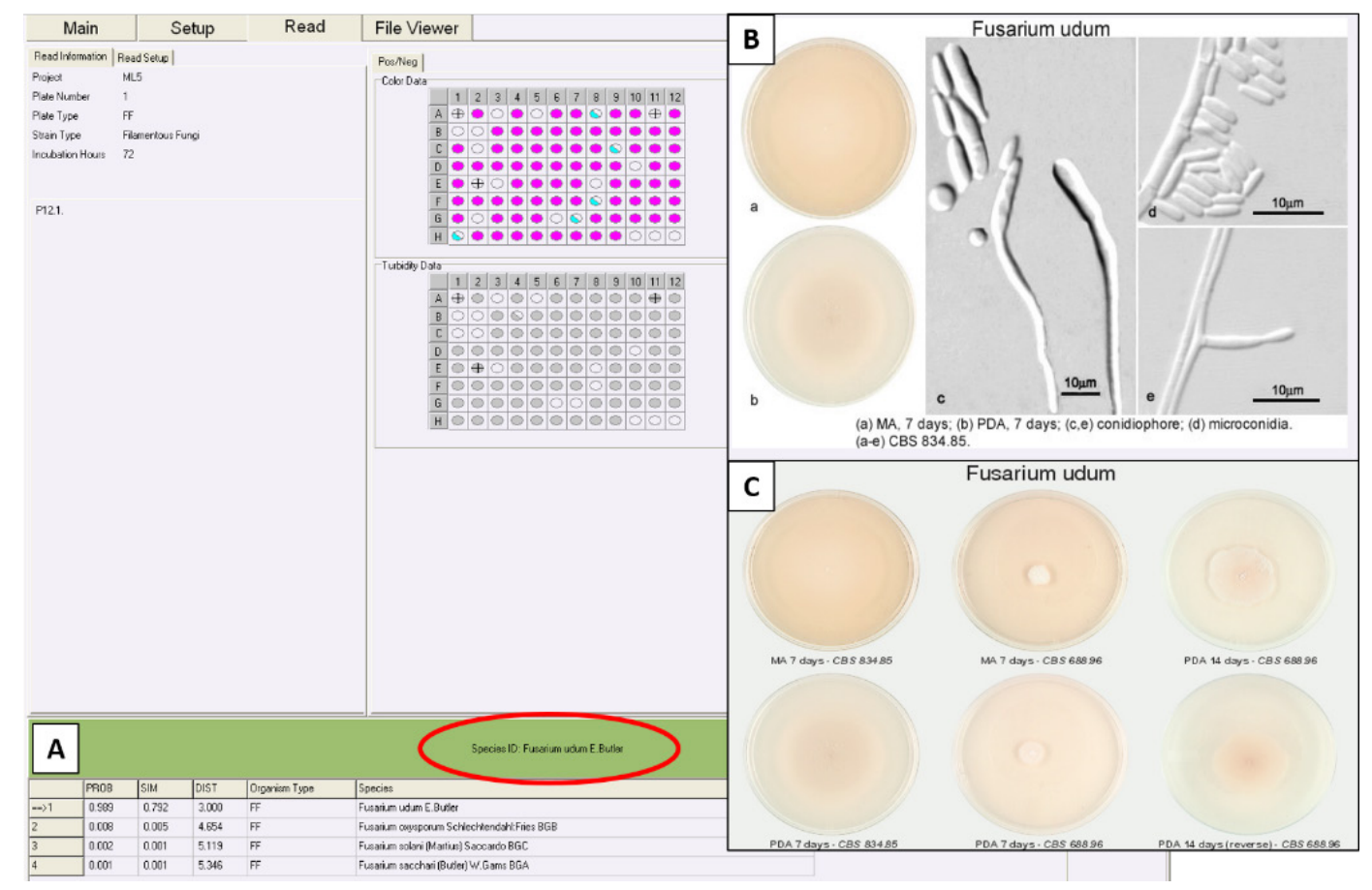

Figure 4. Identification of Fusarium udum using Biolog ${ }^{\circledR}$ system:

(A) identification of F. udum at a similarity of 0.792; (B) microscopic characterization of $F$. udum, as given by the FF Database photo library, for Filamentous Fungi identification;

(C) macroscopic characterization of F. udum, as given by the FF Database 
and the natural co-occurrence of mycotoxins in maize samples contaminated by Fusarium species have been also reported in Italy, South Africa and USA, as mentioned by Ferrigo et al. (2016). Thus, our results might indicate that, in some regions, Romanian maize samples might present a F. udum infection, most probably as result of a previous crop (e.g. pigeon pea crop) contamination with this fungus.

Furthermore, Rhizopus oryzae was confirmed for two control maize samples, one sample from each selected County and one treated sample from Iași County (Fig. 5). Rhizopus oryzae is a filamentous heterothallic fungus, ubiquitous in nature and found on decaying organic material (Meussen et al., 2012). Thus, it usually occurs as a saprotroph in soil, dung and rotting vegetation, being able to convert polymeric agricultural residues and to grow well at a wide temperature range (Meussen et al., 2012). $R$. oryzae strains are often used in Asia for food fermentation to manufacture alcoholic beverages and the strains are generally regarded as safe. Nevertheless, the fungus is also known as an opportunistic human pathogen, having a high prevalence under mucormycosis infections (Meussen et al., 2012).
However, Rhizopus oryzae affects quality and safety of grains. It is usually known as a natural contaminant of maize crops, usually causing growth retardation, but it can be also found as a storage fungus (Rabie et al., 1985; Dawlal et al., 2012). Rabie et al. (1985) noted that $R$. oryzae isolates were highly toxic when grown on maize. $R$. oryzae was also isolated in a percent of $3.42 \%$ from 36 maize samples in Nigeria, while no aflatoxins were detected (Oyeka et al., 2019).

Other isolated fungal species were Aspergillus parasiticus, A. awamori, Fusarium verticillioides and F. solani. Nevertheless, at the end of the incubation period, they all noted levels of the similarity index lower than the acceptable limit for a good identification when using the Biolog ${ }^{\circledR}$ system. However, we can state that at the end of the testing period there was identified a rich and varied microbiota in control samples. A percentage of $71.43 \%$ of the recovered fungal isolates in control samples were identified with a level of the similarity index $>0.50$, which allows the identification to be considered positive, while only for two treated maize samples there could be identified fungal isolates by using the Biolog ${ }^{\circledR}$ system.

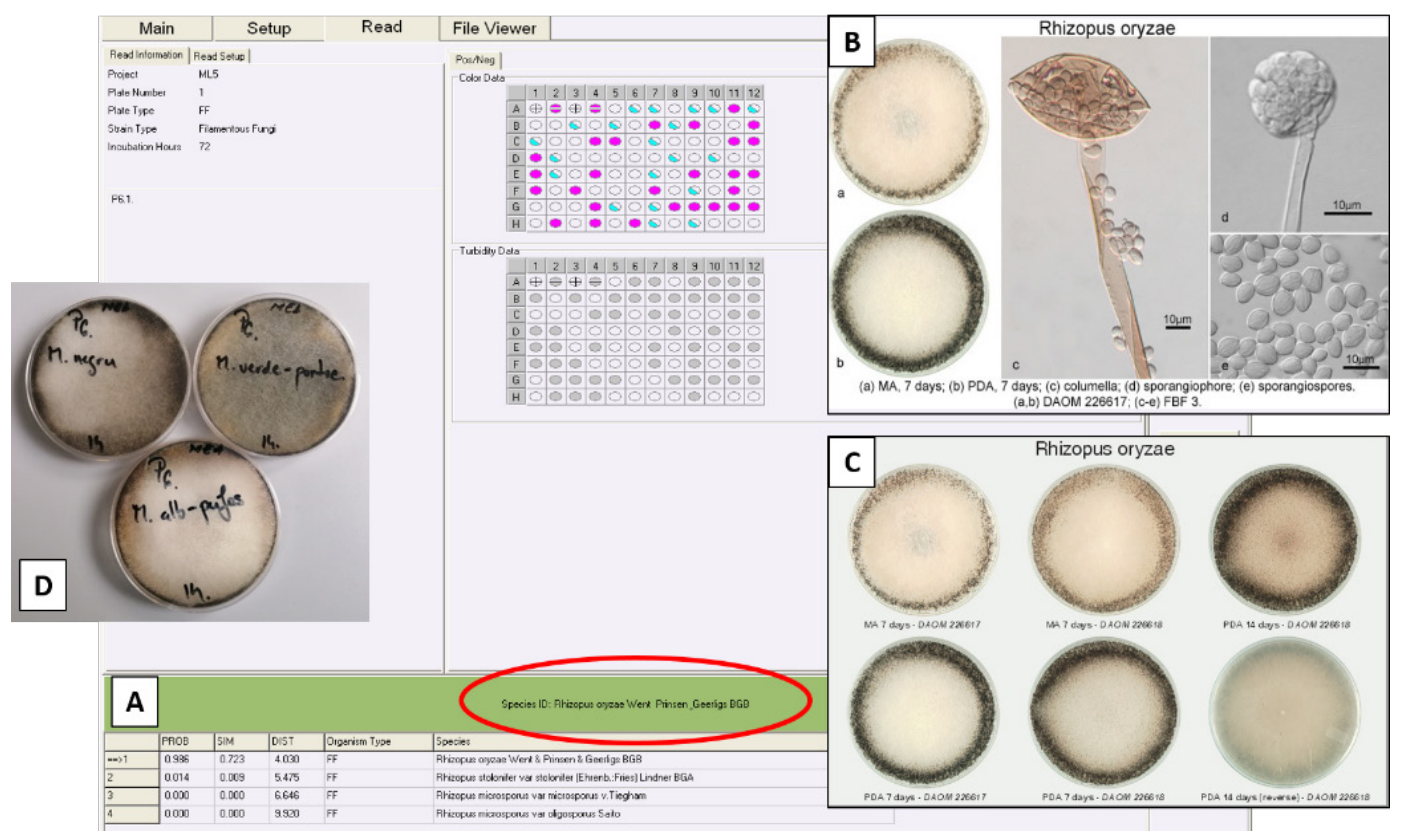

Figure 5. Identification of Rhizopus oryzae using Biolog ${ }^{\circledR}$ system:

(A) identification of $R$. oryzae at a similarity of 0.723 ; (B) microscopic characterization of $R$. oryzae , as given by the FF Database photo library, for Filamentous Fungi identification; (C) macroscopic characterization of $R$. oryzae, as given by the FF Databas; (D) isolated fungus 


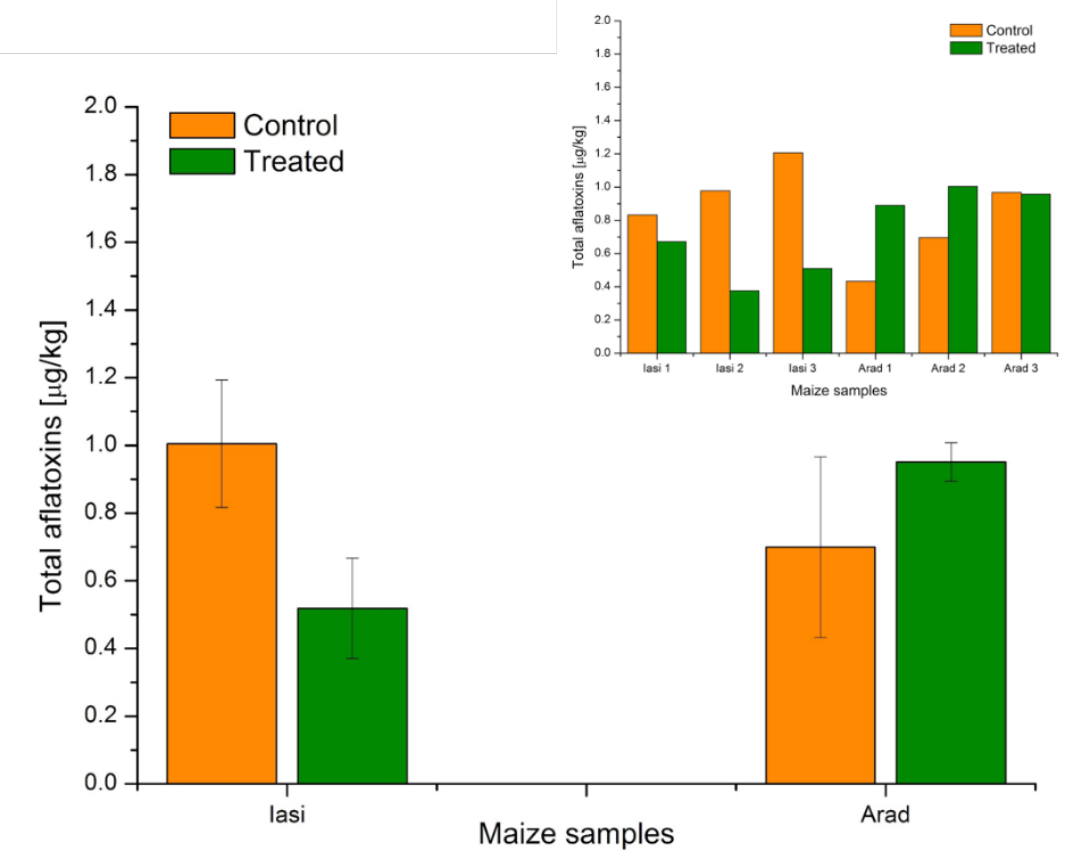

Figure 6. Occurrence of total aflatoxins

\section{Occurrence of total aflatoxins in maize samples}

The current study documents the occurrence of total aflatoxin in the assessed maize samples, along with their microbial load. The uncertainty of the aflatoxin method was $0.34 \mu \mathrm{g} \mathrm{kg}^{-1}$. The results showed low total aflatoxin levels for both type of samples. Thus, the control registered total aflatoxin concentrations below the limit of detection $\left(1.75 \mu \mathrm{g} \mathrm{kg}^{-1}\right)$ of the used ELISA kit for three replicates, while the treated samples only for two replicates (Fig. 6).

The function 'out of rage' of the RidaWin ${ }^{\circledR}$ software was further used, only to receive a rough estimation of the concentrations of total aflatoxins for the assessed samples. There has to be noted that these results present a higher uncertainty and this function was used just as a guideline for any future experimental activities regarding activities of biocontrol of $A$. flavus.

Both control and treated maize fields from two different regions in Romania showed low levels of total aflatoxins. The maximum concentration was $1.21 \mu \mathrm{g} \mathrm{kg}^{-1}$, noted by a control replicate from Iași County, a maize sample not treated with the tested biological treatment. The same sample registered a $R$. oryzae contamination, as this microorganism was isolated and further identified using the Biolog ${ }^{\circledR}$ system.

The obtained results are supported by the results of a 2019 survey regarding the levels of total aflatoxins in Romanian maize samples. The study noted that from 95 randomly collected samples from private cereal farmers from 33 Romanian counties, most of the evaluated samples showed no contamination with aflatoxins beyond threshold set by the European regulations, which stipulates $10.00 \mu \mathrm{g} \mathrm{kg}^{-1}$ as the maximum level of aflatoxins for maize subjected to sorting or other physical treatment before human consumption (EC Commission Regulation No. 1881/2006). Only one sample contained unsafe aflatoxin levels (77.59 $\left.\mu \mathrm{g} \mathrm{kg}^{-1}\right)$ and exceeded the total aflatoxin limit imposed by the European regulations (Smeu et al., 2020).

\section{CONCLUSION}

This study has been aimed at extending knowledge on the occurrence of mycotoxinproducing fungi and total aflatoxins in maize samples, as well as on the application of a semiautomated Biolog ${ }^{\circledR}$ Microbial Identification System for the identification of fungal isolates. Our results indicated that Fusarium udum and Rhizopus oryzae were the prevalent fungi for the assessed maize samples. Both control and treated 
samples showed low levels of total aflatoxins. The registered mycotoxin levels were consistent with the European regulations which stipulates the maximum level of aflatoxins for this commodity. The maximum concentration of total aflatoxins was $1.21 \mu \mathrm{g} \mathrm{kg}^{-1}$, noted by a control replicate not treated with the tested biological treatment. The same sample also registered a $R$. oryzae contamination, a fungus known as a natural contaminant of maize crops, usually causing growth retardation.

For this reason, a better understanding of grain morphological features on total aflatoxin levels for maize cultivars in Romania, as well as a better knowledge on the interrelationship between plant traits and aflatoxin-producing fungi are needed in the development of effective and efficient agronomic practices which favour reduced occurrence of total aflatoxins in regard to specific environmental and climatic conditions.

\section{Acknowledgements}

The present study has received funding by the European Union's Horizon 2020 Research and Innovation Programme under Grant Agreement No. 678781 (MycoKey project). The authors would like to thank the Romanian Ministry of Agriculture and Rural Development for sampling, Lucian Haraga for the field experiments, Constanta Pîrvu and Veta Mertescu for preparing the maize samples for ELISA tests.

\section{REFERENCES}

1. Campbell BC, Molyneux RJ., Schatzki TF (2003). Current research on reducing pre- and post-harvest aflatoxin contamination of US almond, pistachio, and walnut. Journal of Toxicology: Toxin Reviews, 22(2-3): 225-266. Doi: 10.1081/TXR-120024093.

2. Campone L, Piccinelli AL, Celano R, Rastrelli L (2011). Application of dispersive liquid-liquid microextraction for the determination of aflatoxins B1, B2, G1 and G2 in cereal products. Journal of Chromatography A, 1218: 7648-7654. Doi: 10.1016/j.chroma.2011.05.028.

3. Castañares E, Martínez M, Cristos D, Rojas D, Lara B, Stenglein S, Dinolfo MI (2019). Fusarium species and mycotoxin contamination in maize in Buenos Aires province, Argentina. European Journal of Plant Pathology, 155: 1265-1275. Doi: 10.1007/s10658-019-01853-5.

4. Dawlal P, Barros E, Marais GJ (2012). Evaluation of maize cultivars for their susceptibility towards mycotoxigenic fungi under storage conditions. Journal of Stored Products Research, 48: 114-119. Doi: 10.1016/j.jspr.2011.10.006.

5. Díaz-Zaragoza M, Carvajal-Moreno M, Méndez-Ramírez I, Chilpa-Galván NC, Ávila-González Flores-Ortiz C.M. (2014). Aflatoxins, hydroxylated metabolites, and aflatoxicol from breast muscle of laying hens. Poultry Science, 93(12): 3152-3162. Doi: 10.3382/ps.2014-04240.

6. Döll S, Dänicke S (2011). The Fusarium toxins deoxynivalenol (DON) and zearalenone (ZON) in animal feeding. Preventive Veterinary Medicine, 102, 1332-145. Doi: 10.1016/j.prevetmed.2011.04.008.

7. Ekwomadu TI, Gopane RE, Mwanza M (2018). Occurrence of filamentous fungi in maize destined for human consumption in South Africa. Food Science and Nutrition, 6(4): 884-890. Doi: 10.1002/fsn3.561.

8. Eom S-Y, Yim D-H, Zhang Y, Yun J-K, Moon SI, Yun H-Y, Sog Y-J, Youn S-J, Hyun T, Park J-S, Kim BS, Lee J-Y, Kim Y-D, Kim H (2013). Dietary aflatoxin B1 intake, genetic polymorphisms of CYP1A2, CYP2E1, EPHX1, GSTM1, and GSTT1, and gastric cancer risk in Korean. Cancer Causes Control, 24(11): 1963-72. Doi: 10.1007/s10552-0130272-3.

9. European Commission (2006): Commission Regulation (EC) No. 1881/2006 of 19 December 2006 setting maximum levels for certain contaminants in foodstuffs. Official Journal of the European Union L364: 5-24.

10. EUROSTAT (European Statistical Office). (2020a). Cereals for the production of grain (including seed) by area, production and humidity. Available at: https://ec.europa. eu/eurostat/web/products-datasets/-/tag 00027. Accessed 26.03.2020

11. EUROSTAT (European Statistical Office). (2020b). Grain maize and corn-cob-mix by area, production and humidity. Available at: https://ec.europa.eu/eurostat/web/ products-datasets/-/tag00093. Accessed 30.03.2020

12. Fallahi M, Saremi H, Javan-Nikkhah M, Somma S, Haidukowski M, Logrieco AF, Moretti A (2019). Isolation, molecular identification and mycotoxin profile of Fusarium species isolated from maize kernels in Iran. Toxins, 11: 297. Doi: 10.3390/toxins11050297.

13. Fedeles BI, Chawanthayatham S, Croy RG, Wogan GN, Essigmann JM (2017). Early detection of the aflatoxin B1 mutational fingerprint: A diagnostic tool for liver cancer. Molecular \& Cellular Oncology, 4(4): e1329693. Doi: 10.1080/23723556.2017.1329693.

14. Ferrigo D, Raiola A, Causin R (2016). Fusarium toxins in cereals: Occurrence, legislation, factors promoting the appearance and their management. Molecules, 21(5): 627. Doi: 10.3390/molecules21050627.

15. Fotso J, Leslie JF, Smith JS (2002). Production of beauvericin, moniliformin, fusaproliferin and fumonisins B1, B2, and B3 by fifteen ex-type strains of Fusarium species. Applied and Environmental Microbiology, 51955197. Doi: 10.1128/AEM.68.10.5195-5197.2002.

16. Georggiett OC, Muiño JC, Montrull H, Brizuela N, Avalos S, Gómez RM (2000). Estudio de la relación entre aflatoxina B1 y cáncer de pulmón [Relationship between lung cancer and aflatoxin B1]. Revista de la Facultad de Ciencias Medicas (Cordoba, Argentina), 57(1): 95-107. Spanish. PMID: 11188861.

17. IARC (International Agency for Research on Cancer). (1993). IARC monograph on the evaluation of carcinogenic risk to humans. Volume 56: Some naturally occurring substances: Food items and constituents, heterocyclic 
aromatic amines and mycotoxins. ISBN 9283212568 (Lyon, France).

18. INS (Institutul Național de Statistică). (2019). Producția vegetală la principalele culturi în anul 2018. Available at: https://insse.ro/cms/sites/default/files/field/ publicatii/productia_vegetala_la_principalele_culturi_in_ anul_2018_1.pdf. Accessed 26.03.2020.

19. Jaime-Garcia R, Cotty PJ (2003). Aflatoxin contamination of commercial cottonseeds in south Texas. Phytopathology, 93(9): 1190-1200. Doi: 10.1094/PHYTO.2003.93.9.1190.

20. Kagot V, Okoth S, De Boevre M, De Saeger S (2019). Biocontrol of Aspergillus and Fusarium mycotoxins in Africa: Benefits and limitations. Toxins, 11: 109. Doi: 10.3390/toxins11020109.

21. Klich MA (2007). Aspergillus flavus: the major producer of aflatoxin. Molecular plant patology, 8(6): 713-722. Doi: 10.1111/j.1364-3703.2007.00436.x.

22. Lević J, Gošić-Dondo S, Ivanović D, Stanković S, Krnjaja V, Bočarov-Stančić A, Stepanić A (2013). An outbreak of Aspergillus species in response to environmental conditionsinSerbia.Journal Pesticides and Phytomedicine, 28(3): 167-179. Doi: 10.2298/PIF1303167L.

23. Li W, Herrman TJ, Dai SY (2010). Determination of aflatoxins in animal feeds by liquid chromatography/ tandem mass spectrometry with isotope dilution. Rapid Communications in Mass Spectrometry, 25: 1222-1230. Doi: $10.1002 / \mathrm{rcm} .4979$.

24. Lien K-W, Wang X, Pan M-H, Ling M-P (2019). Assessing aflatoxin exposure risk from peanuts and peanut products imported to Taiwan. Toxins, 11(2): 80. Doi: 10.3390/ toxins11020080.

25. Majeed S, Iqbal M, Asi MR, Iqbal SZ (2013). Aflatoxins and ochratoxin A contamination in rice, corn and corn products from Punjab, Pakistan. Journal of Cereal Science, 58: 446-450. Doi: 10.1016/j.jcs.2013.09.007.

26. Mauro A, Garcia-Cela E, Pietri A, Cotty PJ, Battilani $P$ (2018). Biological control products for Aflatoxin prevention in Italy: Commercial field evaluation of atoxigenic Aspergillus flavus active ingredients. Toxins, 10: 30. Doi: $10.3390 /$ toxins10010030.

27. Meca G, Sospedra I, Soriano JM, Ritieni A, Valero MA, Mañes J (2009). Isolation, purification and antibacterial effect of fusaproliferin produced by Fusarium subglutinans in submerged culture. Food and Chemical Toxicology, 47: 2539-2543. Doi: 10.1016/j.fct.2009.07.014.

28. Meussen BJ, de Graaff LH, Sanders JPM, Weusthuis RA (2012). Metabolic engineering of Rhizopus oryzae for the production of platform chemicals. Applied Microbiology and Biotechnology, 94(4): 875-886. Doi: 10.1007/ s00253-012-4033-0.

29. Moretti A, Mulè G, Ritieni A, Logrieco A (2007). Further data on the production of beauvericin, enniatins and fusaproliferin and toxicity to Artemia salina by Fusarium species of Gibberella fujikuroi species complex. International Journal of Food Microbiology, 118: 158-163. Doi: 10.1016/j.ijfoodmicro.2007.07.004.

30. Mutiga SK, Chepkwony N, Hoekenga OA, Flint-Garcia SA, Nelson RJ (2019). The role of ear environment in postharvest susceptibility of maize to toxigenic Aspergillus flavus. Plant Breeding, 138(1): 38-50.

31. Ngindu A, Kenya PR, Ocheng DM, Omondi TN, Ngare W, Gatei D, Johnson B, Ngira JA, Nandwa H, Jansen A, Kaviti JN, Arap Siongok T (1982). Outbreak of acute hepatitis caused by aflatoxin poisoning in Kenya. The Lancet, 319(8285): 1346-1348. Doi: 10.1016/S0140-6736(82)92411-4.

32. Oyeka CA, Amasiani RN, Ekwealor CC (2019). Mycotoxins contamination of maize in Anambra State, Nigeria. Food Additives and Contaminants: Part B, 12(4): 280-288. Doi: 10.1080/19393210.2019.1661528.

33. Pfenning LH, Pereira de Melo M, Moreira Costa M, Reis A, Santos Cabral C, Lima CS, Abreu LM, Costa SS (2019). Fusarium udum revisited: a common, but poorly understood member of the Fusarium fujikuroi species complex. Mycological Progress, 18: 107-117. Doi: 10.1007/s11557-018-1446-x.

34. Piva G, Battilani P, Pietri A (2006). Emerging issues in Southern Europe: Aflatoxins in Italy. In Barug, D., Bhatnagar, D., van Egmond, H.P., van der Kamp, J.W., van Osenbruggen, W.A., Visconti, A. (Eds). The mycotoxin fact book (pp.139-153). Wageningen Academic Publishers: Wageningen, The Netherlands.

35. Puel O, Galtier P, Oswald IP (2010). Biosynthesis and toxicological effects of patulin. Toxins, 2: 613-631. Doi: 10.3390/toxins2040613.

36. Rabie CJ, Lubben A, Schipper MAA, van Heerden FR, Fincham JE (1985). Toxigenicity of Rhizopus species. International Journal of Food Microbiology, 1(5): 263270. Doi: 10.1016/0168-1605(85)90018-2.

37. Singh MP (2009). Application of Biolog FF MicroPlate for substrate utilization and metabolite profiling of closely related fungi. Journal of Microbiological Methods, 77: 102-108. Doi: 10.1016/j.mimet.2009.01.014.

38. Singh P, Cotty PJ (2017). Aflatoxin contamination of dried red chilies: Contrasts between the United States and Nigeria, two markets differing in regulation enforcement. Food Control, 80: 374-379. Doi: 10.1016/j. foodcont.2017.05.014.

39. Smeu I, Cucu EM, Dobre AA, Casian H. (2020). A 2019 study on total aflatoxins in Romanian maize (Zea mays L.) samples. Romanian Journal of Plant Protection, XIII, 1-8, ISSN 2248-129X; ISSN-L 2248-129X.

40. Sobrova P, Adam V, Vasatkova A, Beklova M, Zeman L, Kizek R (2010). Deoxynivalenol and its toxicity. Interdisciplinary Toxicology, 3(3): 94-99. Doi: 10.2478/ v10102-010-0019-x.

41. Srivastava AK, Kashyap PL, Chakdar H, Kumar M, Srivastava AK, Yadav J, Jamali H, Srivastava R, Sharma A, Tiwari P, Singh A, Saxena AK (2018). First de novo draft genome sequence of the pathogenic fungus Fusarium udum F02845, associated with pigeonpea (Cajanus cajan $\mathrm{L}$. millspaugh) wilt. Microbiology Resource Announcements, 7: e01001-18. Doi: 10.1128/MRA.01001-18.

42. Sserumaga JP, Ortega-Beltran A, Wagacha JM, Mutegi CK, Bandyopadhyay R (2020). Aflatoxin-producing fungi associated with pre-harvest maize contamination in Uganda. International Journal of Food Microbiology, 313: 108376. Doi: 10.1016/j.ijfoodmicro.2019.108376. 
43. Tadesse S, Berhanu T, Woldegiorgis AZ (2020).Aflatoxin M1 in milk and milk products marketed by local and industrial producers in Bishoftu town of Ethiopia. Food Control, 118: 107386. Doi: 10.1016/j.foodcont.2020.107386.

44. USDA (United States Department of Agriculture), (2020). World Agricultural Production. Available at: https:// apps.fas.usda.gov/psdonline/circulars/production.pdf Accessed 26.03.2020.

45. Wang H, Wang J, Chen Q, Wang M, Hsiang T, Shang S, Yu Z (2016). Metabolic effects of azoxystrobin and kresoximmethyl against Fusarium kyushuense examined using the Biolog FF MicroPlate. Pesticide Biochemistry and Physiology, 130: 52-58. 